Pak. j. sci. ind. res. Ser. B: biol. sci. 201255 (2) 101-107

\title{
Changes in Bacillus thuringiensis Tolerance Levels Due to Hybridization of Bt-Tolerant and Susceptible Silkworm Populations
}

\author{
Hosne Ara Begum $^{\text {ad* }}{ }^{\text {Errol Hassan }}{ }^{a}$, John Dingle ${ }^{b}$ and Aisha Alkhayat Alshehi ${ }^{c}$ \\ ${ }^{a}$ School of Agronomy and Horticulture, University of Queensland, Gatton, Queensland 4345, Australia \\ bSchool of Animal Studies, University of Queensland, Gatton, Queensland 4345, Australia \\ ${ }^{\mathrm{c}}$ Department of Biology, College of Science, Sultan Qaboos University, Al-Khod 123, Oman \\ ${ }^{\mathrm{d}} \mathrm{c} / \mathrm{o}$ Department of Biology, Sultan Qaboos University, PO Box 36, Al-Khod 123, Muscat, Oman
}

(received September 12, 2011; revised June 8, 2012; accepted June 20, 2012)

\begin{abstract}
Males and females of a Bt-tolerant mulberry silkworm (Bombyx mori L.) population were crossed with females and males of a Bt-susceptible population, to produce Bt-tolerant silkworm hybrids, and to determine the expression of the Bt-tolerance pattern in the F1 hybrids. It was observed that when a Bt-tolerant (42\% larval mortality) female (BtT + ) silkworm was crossed with a Bt-susceptible (85\% larval

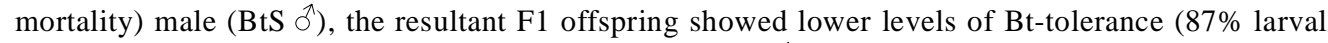
mortality). On the other hand, when a Bt-tolerant male (BtT $\delta^{\Uparrow}$ ) was crossed with a Bt-susceptible female (BtS ${ }^{+}$), the F1 hybrid showed higher levels of Bt-tolerance (35\% larval mortality) characteristic. The probit statistics showed that both hybrids expressed Bt-tolerance or susceptible levels similar to their male parents. These different patterns of Bt-tolerance in F1 hybrids might be due to the transferring of a Bttolerant gene, from the parents to offspring, through the homozygotic male (ZZ) silkworm.
\end{abstract}

Keywords: Bacillus thuringiensis, Bt-tolerance, Bombyx mori, insect hybridization, male homozygosity, hybrid performances

\section{Introduction}

Different commercial preparations of Bacillus thuringiensis (Bt) have been sold and used as biopesticides against crop pests worldwide. Natural Bt is also commonly present on Japanese mulberry plants especially on the leaves (Ohba, 1996). When ingested by silkworm larvae, the parasporal inclusions of $\mathrm{Bt}$ are dissolved in larval midgut juice and release protoxins. The Bt Cry1 proteins are specifically toxic to lepidopteran larvae including the Bombyx mori. These toxins are solubilized and enzymatically processed in the midgut of susceptible insects. The activated toxins interact with the larval epithelial membrane and induce pore formation in the membrane, which ultimately leads to insect death (McNall and Adang, 2003; Morin et al., 2003). It was reported that the Bt toxins kill insects by binding to specific target sites and disrupting the midgut tissue followed by septicemia (Raymond et al., 2010; Ibiza-Palacios et al., 2008). The Bt affected larvae gradually become brown to black-brown and finally when rotting they turn black (Aruga, 1994).

*Author for correspondence; E-mail: H.A.Begum@gmail.com
Silkworm (Bombyx mori L.) larvae are highly susceptible to $B$. thuringiensis (Bt), causing over $50 \%$ mortality of $4^{\text {th }}$ instar larvae at a low concentration of $0.01 \%$ of $\mathrm{Bt}$ (Pramanik and Somchoudhury, 2001). The silkworm larvae were also found as 2,500-fold more susceptible to the Bt var. kurstaki infection than Spodoptera litura larvae (Inagaki et al., 1992). B. thuringiensis is considered to be the causative agent for flacherie disease of silkworms. Countries with established sericulture industries fear a Bt induced disease out-break and restrict the use of Bt in silkworm/ mulberry growing areas (Van Driesche and Bellows, 1996).

The Bt is widely used in vegetable growing areas of Australia. The establishment of a new sericulture industry in Australia might encounter Bt related disease problems, either from mulberry leaf sources or from the ingress of Bt pesticides from nearby crop areas (Begum et al., 2004). As it is difficult to exclude pathogens from the silkworm rearing environment, Bt might be a major constraint in the silkworm disease management (Balavenkatasubbaiah et al., 1999). Thus, it is important to develop Bt-tolerant silkworm races for the future 
Australian sericulture industry. Rahman et al. (2004) reported that they were able to transmit the Bt-tolerance properties to offspring by a maternal effect in case of flour moth (Ephestia kuehniella). However, the reports on the changes of Bt-tolerance levels due to hybridization in silkworm are not available.

The present investigation was carried out to test the development of Bt-tolerant new silkworm populations through conventional hybridization between a Bt-tolerant and a Bt-susceptible population; to compare the Bttolerance levels in the hybrids and parents; and to note the transfer pattern of the Bt-tolerant character (gene) from parents to hybrids.

\section{Materials and Methods}

Silkworm populations. One Australian (QuBill) and one Indonesian (Insab) silkworm population were used for the present research study. The "QuBill” is a silkworm strain of Queensland origin with oval shaped yellow coloured cocoon. The "Insab" is a silkworm strain of Indonesian origin with a peanut shaped white coloured cocoon. All insect rearing and experiments were done in a growth chamber at $25 \pm 2{ }^{\circ} \mathrm{C}$ temperature, $75 \pm 2 \%$ relative humidity and 16: 8 h light : dark conditions. All the experiments were set in a Completely Randomized Block Design (CRBD) with four replications.

Bt insecticide. Dipel ${ }^{\circledR}$, a commercial preparation of B. thuringiensis var kurstaki, was used as a source of Bt-insecticide (Aurther Yates and Co. Ltd, Australia, active constituents: 4320 international units of potency per $\mathrm{mg}$ of $B$. thuringiensis var. kurstaki). The preparation of the stock solution was done by suspending $66.7 \mathrm{mg}$ of Dipel ${ }^{\circledR}$ in $100 \mathrm{~mL}$ of distilled water (strength: $2881.44 \mathrm{IU} / \mathrm{mL}$ ), so that stock concentration hold $100 \mu \mathrm{g}$ Dipel $/ 150 \mu \mathrm{L}$ solution. All further dilutions (80, 60 and $40 \mu \mathrm{g} / 150 \mu \mathrm{L}$ solution) were made from this stock.

Establishing Bt-tolerant population. For two consecutive generations, the Insab population at $3^{\text {rd }}$ instar larval stage, were treated with one of the three specific doses of $\mathrm{Bt}(80,60$ and $40 \mu \mathrm{g} / 150 \mu \mathrm{L}$ solution) according to the method described by Begum et al. (2004). After $72 \mathrm{~h}$ of observations, the surviving larvae were separately reared and allowed to reproduce. As a result, at the $3^{\text {rd }}$ generation, a comparatively Bt-tolerant Insab population appeared (30 - 43\% larval mortality at $80 \mu \mathrm{g} / \mathrm{disc}$ dose). This was used as the "Bt-tolerant parent (BtTIns)”. On the other hand, the QuBill population was also treated with the same Bt doses and was found to be as highly susceptible to Bt infection (60 - 85\% larval mortality). This QuBill population was used as the "Bt-susceptible parent (BtSQuB)".

Hybridization techniques. The eggs from both parent (Bt- tolerant and susceptible) populations were set for hatching and tested for Bt-tolerance at the $3^{\text {rd }}$ instar stage. After 72 h 50 surviving larvae from each population (treated with $80 \mu \mathrm{g} /$ disc dose) were selected and reared. All larvae were provided with fresh mulberry leaves collected from field grown mulberry trees. At maturity, the larvae were transferred to purpose built paper mountages (set inside a plastic box) for the spinning of cocoons. The cocoons were harvested and cleaned over a week of post-spinning. The healthy similar sized cocoons were kept in separate plastic boxes until the emergence of adults. On the morning of the day of emergence, a female (Bt-SQuB $\left.{ }^{\circ}\right)$ moth of Bt-susceptible QuBill parents was paired with a male (Bt-TIns ${ }^{7}$ ) moth of Bt tolerant Insab parents. Similarly, a female (Bt-TIns 9 ) moth from Bt tolerant Insab parent was paired with a male (BtSQuB $\widehat{\jmath})$ moth of Bt-susceptible QuBill parent. The coupled pairs were kept enclosed under an inverted funnel for the next 7-8 h, after which couples were separated and each female moth was placed on separate pre-labelled filter paper (Whatman, $9 \mathrm{~cm}$ diameter) and enclosed with an inverted funnel. The females were kept in the dark overnight and the next morning they were removed from the filter paper. The filter papers with silkworm eggs were used for the hatching and developing two different hybrids namely: "BtSQuB $+\times$ BtTIns o 0 (QuB-Ins hybrid)" and "BtTIns $+\times$ BtSQuB ơ (Ins-QuB hybrid)".

Bt treatments. Both the hybrid populations were separately reared in the growth chambers as described above. When the hybrid populations reached the $3^{\text {rd }}$ instar larval stage, they were treated with one of three doses of Bt $(40,60$ and $80 \mu \mathrm{g} / 150 \mu \mathrm{L}$ solution) according to the method described by Begum et al. (2004). Four replications were used for each Bt dose and 10 larvae were included in each replication. At the end of $24 \mathrm{~h}$, the larval mortality was counted in each replication. After removing the dead, all surviving larvae were transferred to new plastic containers and fed with untreated fresh mulberry leaves. Larval mortalities were also recorded at 48 and 72 "hours after treatment” (HAT), with all dead larvae removed from the containers. 
Statistical Analysis. The original mortality data were transformed into arcsine percentage values and then analyzed using ANOVA and Duncan's multiple range test (Duncan, 1951). Bt concentration - larval mortality relationships were calculated using probit analysis (Finney, 1971) with a $\log _{10}$ transformation of concentrations of Bt. Results $\left(\mathrm{LD}_{50}\right)$ were expressed as micrograms of Dipel ${ }^{\circledR}$ per leaf disc ( $\mu \mathrm{g} /$ disc).

\section{Results and Discussion}

Results from the investigations on the relative Bttolerance levels in two different hybrid silkworm populations ("QuB-Ins hybrid" and "Ins-QuB hybrid") in relation to their parents (Insab and QuBill), against three different doses of B. thuringiensis var kurstaki, are given below.

Hybridization effects of silkworm populations. The comparative Bt-tolerance and susceptible responses of two new hybrids namely, "QuB-Ins hybrid" and "Ins-
QuB hybrid” populations in relation to their parents (QuBill and Insab) showed that Bt possessed different levels of toxicity against these silkworm populations (Table 1). Among the experimental four populations, "Ins-QuB hybrid" showed the highest Bt-susceptibility rate (87.5\% larval mortality at 72 HAT with $80 \mu \mathrm{g}$ Dipel ${ }^{\circledR} /$ disc dose), which was close to but higher than its male QuBill parent (85\% mortality). On the other hand the "QuB-Ins hybrid" showed the highest Bttolerance level (35\% larval mortality at 72 HAT with $80 \mu \mathrm{g}$ Dipel ${ }^{\circledR} /$ disc dose), which was close but lower than its male Insab parent (42.50\% mortality). When all the four silkworm populations were compared for 24, 48 and $72 \mathrm{~h}$ after treatment (24, 48 \& 72 HAT), it was found that the Bt-tolerance or Bt-susceptibility response of the "QuB-Ins hybrid" was similar to its male Insab parent, whereas the Bt-tolerance responses of "Ins-QuB hybrid" showed very similar tolerance levels to its male QuBill parent (Fig. 1).

Table 1. Larval mortality in hybrids and parent silkworm populations due to the application of different Bt doses on leaf discs

\begin{tabular}{|c|c|c|c|c|}
\hline \multirow{2}{*}{$\begin{array}{l}\text { Population and Bt } \\
\text { concentration ( } \mu \mathrm{g} / \mathrm{disc})\end{array}$} & \multirow{2}{*}{$\begin{array}{l}\text { No. of } \\
\text { treated insects }\end{array}$} & \multicolumn{3}{|c|}{ Larval mortality percentages at } \\
\hline & & 24 HAT & 48 HAT & 72 HAT \\
\hline \multicolumn{5}{|l|}{ QuBill: } \\
\hline 80 & 40 & $60.00 \pm 4.08 \mathrm{a}$ & $82.50 \pm 4.79 \mathrm{a}$ & $85.00 \pm 2.89 \mathrm{a}$ \\
\hline 60 & 40 & $57.50 \pm 4.79 \mathrm{a}$ & $75.00 \pm 2.89 \mathrm{a}$ & $77.50 \pm 2.50 \mathrm{a}$ \\
\hline 40 & 40 & $32.50 \pm 4.79 b$ & $55.00 \pm 8.66 b$ & $60.00 \pm 4.08 b$ \\
\hline Control & 40 & 0 & 0 & 0 \\
\hline \multicolumn{5}{|l|}{ Insab: } \\
\hline 80 & 40 & $30.00 \pm 7.07 \mathrm{a}$ & $40.00 \pm 7.07 \mathrm{a}$ & $42.50 \pm 7.50 \mathrm{a}$ \\
\hline 60 & 40 & $22.50 \pm 2.50 \mathrm{a}$ & $30.00 \pm 4.08 \mathrm{a}$ & $30.00 \pm 4.08 \mathrm{ab}$ \\
\hline 40 & 40 & $20.00 \pm 7.07 \mathrm{a}$ & $22.50 \pm 8.54 \mathrm{a}$ & $22.50 \pm 8.54 \mathrm{~b}$ \\
\hline Control & 40 & 0 & 0 & 0 \\
\hline \multicolumn{5}{|l|}{ QuB-Ins hybrid: } \\
\hline 80 & 40 & $7.50 \pm 4.79 \mathrm{a}$ & $30.00 \pm 8.17 \mathrm{a}$ & $35.00 \pm 4.08 \mathrm{a}$ \\
\hline 60 & 40 & $5.00 \pm 2.89 \mathrm{a}$ & $25.00 \pm 5.00 \mathrm{a}$ & $25.00 \pm 5.00 \mathrm{ab}$ \\
\hline 40 & 40 & 0 & $12.50 \pm 4.79 \mathrm{a}$ & $15.00 \pm 6.46 \mathrm{~b}$ \\
\hline Control & 40 & 0 & 0 & 0 \\
\hline \multicolumn{5}{|l|}{ Ins-QuB hybrid: } \\
\hline 80 & 40 & $40.00 \pm 7.07 \mathrm{a}$ & $87.50 \pm 4.79 a$ & $87.50 \pm 4.79 a$ \\
\hline 60 & 40 & $30.00 \pm 7.07 \mathrm{ab}$ & $67.50 \pm 8.54 b$ & $67.50 \pm 4.79 b$ \\
\hline 40 & 40 & $22.50 \pm 4.79 \mathrm{~b}$ & $62.50 \pm 2.50 \mathrm{~b}$ & $65.00 \pm 2.89 b$ \\
\hline Control & 40 & 0 & 0 & 0 \\
\hline
\end{tabular}

*Population means within a column followed by the same letter are not significantly different at the 5\% level (Duncan's Multiple Range Test); * HAT = hours after treatment. 


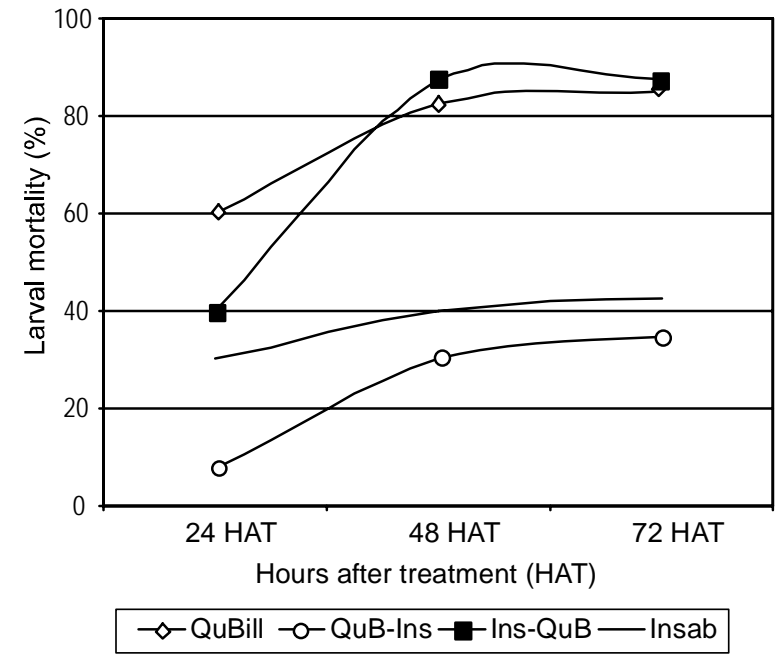

Fig. 1. Relationship between the mortalities of male parents and hybrids at 24, 48 and $72 \mathrm{~h}$ after Bt treatment (80 $\mu \mathrm{g} /$ disc).

Probit statistics. The $\mathrm{LD}_{50}$ probit analysis estimates of larval mortalities of two new hybrids and their parents are presented in Table 2 and Figs. 2-3. Comparison of $\mathrm{LD}_{50}$ 's on the basis of the probit analyses at 48 and
72 "hours after treatment", showed that at 48 HAT, the 'Ins-QuB hybrid' had the lowest $\mathrm{LD}_{50}$ (32.06 $\mu \mathrm{g} \mathrm{Dipel}^{\circledR}$ /disc dose) among the tested 4 populations, closely followed by its male parent "QuBill” (LD ${ }_{50} 35.48$ $\mu \mathrm{g} /$ disc) (Table 2). Similar trends were observed at 72 HAT, where the 'Ins-QuB hybrid' had the lowest $\mathrm{LD}_{50}$ (29.44 $\mu$ g Dipel $^{\circledR} /$ disc dose), closely followed by its male parent “QuBill” (LD $5031.85 \mu \mathrm{g} /$ disc).

On the other hand, the "QuB-Ins hybrid" showed the highest $\mathrm{LD}_{50}$ at $48 \mathrm{HAT}(137.28 \mu \mathrm{g} /$ disc dose) and 72 HAT (121.40 $\mu \mathrm{g} /$ disc dose), followed by its male parent “Insab” (LD 50117.38 and $105.61 \mu \mathrm{g} /$ disc dose, respectively). Although at 24 HAT, both the parents showed better performances than their hybrids, with the advancement of time (48 \& 72 HAT) they lost their superiority to their hybrids (Table 2).

Probit regression lines. When the probit mortalities of different parents and hybrids were compared with Bt concentrations through probit regression analyses, hybrid mortalities were positively correlated with the male parents and Bt concentrations (Fig. 2-3). The probit regression lines for the effects of $\mathrm{Bt}$ on different parents and hybrids showed clear linear relationships

Table 2. Probit analysis for lethality of different Bt concentrations on two parents and two hybrid populations of mulberry silkworm, Bombyx mori

\begin{tabular}{|c|c|c|c|c|c|}
\hline Silkworm population & $\begin{array}{l}\text { No. of } \\
\text { larvae }\end{array}$ & $\begin{array}{l}\mathrm{LD}_{50} \\
\text { ( } \mu \mathrm{g} / \text { disc })\end{array}$ & $\chi^{2}$ value & $\begin{array}{l}\text { 95\% fiducial } \\
\text { limit }\end{array}$ & Slope \pm S.E. \\
\hline \multicolumn{6}{|l|}{ QuBill: } \\
\hline 24 HAT & 120 & 57.79 a & 2.16 & $3.80-870.96$ & $2.43 \pm 0.60$ \\
\hline 48 HAT & 120 & 35.48 a & 0.20 & $2.00-630.96$ & $2.74 \pm 0.64$ \\
\hline 72 HAT & 120 & 31.85 a & 0.03 & $1.70-630.96$ & $2.62 \pm 0.65$ \\
\hline \multicolumn{6}{|l|}{ Insab: } \\
\hline 24 HAT & 120 & 278.13 a & 0.34 & $14.79-5128.61$ & $1.03 \pm 0.65$ \\
\hline 48 HAT & 120 & 117.38 a & 0.15 & $6.92-1995.26$ & $1.66 \pm 0.63$ \\
\hline 72 HAT & 120 & $105.61 \mathrm{~b}$ & 0.38 & $6.17-1778.28$ & $1.87 \pm 0.63$ \\
\hline \multicolumn{6}{|l|}{ QuB-Ins Hybrid: } \\
\hline 24 HAT & 120 & $180.21 \mathrm{a}$ & 1.70 & $0.23-141253.75$ & $3.85 \pm 1.47$ \\
\hline 48 HАТ & 120 & $137.28 \mathrm{~b}$ & 0.42 & $6.31-3019.95$ & $2.07 \pm 0.68$ \\
\hline 72 HAT & 120 & $121.40 \mathrm{~b}$ & 0.01 & $6.03-2398.83$ & $2.16 \pm 0.66$ \\
\hline \multicolumn{6}{|l|}{ Ins-QuB hybrid: } \\
\hline 24 HAT & 120 & $117.38 \mathrm{a}$ & 0.15 & $6.92-1995.26$ & $1.66 \pm 0.63$ \\
\hline 48 HAT & 120 & $32.06 \mathrm{~b}$ & 4.39 & $1.78-588.84$ & $2.45 \pm 0.64$ \\
\hline 72 HAT & 120 & $29.44 b$ & 5.12 & $1.62-537.03$ & $2.21 \pm 0.64$ \\
\hline
\end{tabular}

*Values followed by the same letter within a column are not significantly different at the 0.05 level $(\mathrm{P}=0.05)$; $\mathrm{LD}_{50}=\mathrm{Lethal}$ median dose; $\chi^{2}=$ chi-square, goodness-of-fit test [the tabulated $\chi^{2}$ value is $3.84(\mathrm{df}=1, \mathrm{p}<0.05)$ ]; S.E. $=$ Standard error. 
between hybrids with their male parents and also with Bt concentrations. At 48 and 72 HAT, the probit mortality lines for the 'Ins-QuB hybrids' closely followed their male parent 'QuBill'. Similarly, the probit mortality lines followed their male parents 'Insab'. These close relationships between the mortalities of both hybrids and their male parents suggest the possibility of transmission of Bt resistance characters from the male parents to their hybrids.

As the silkworm larvae were treated with more Bt toxin at higher concentrations, the slopes of the probit lines became

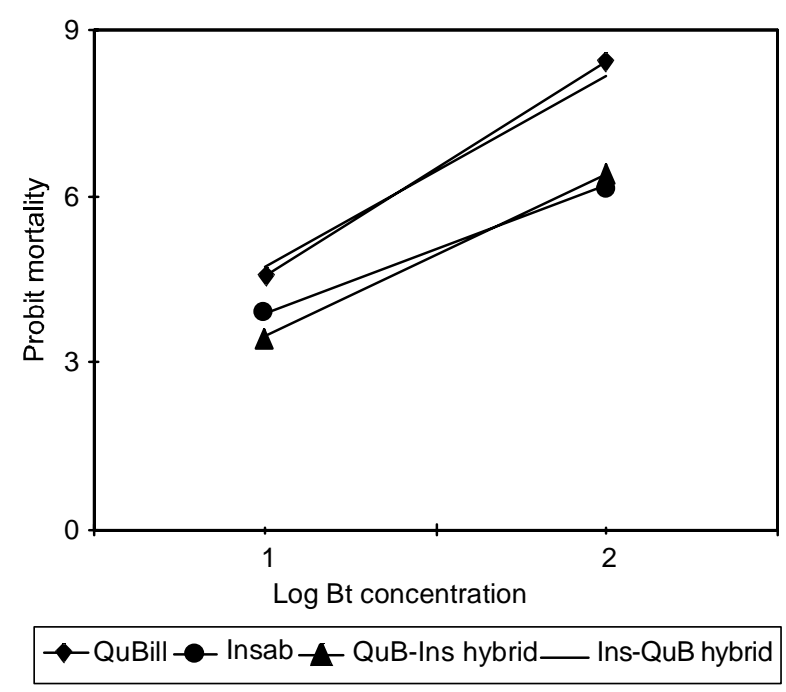

Fig. 2. Bt Concentration - Probit mortality in parents and hybrids at $48 \mathrm{~h}$ after treatment.

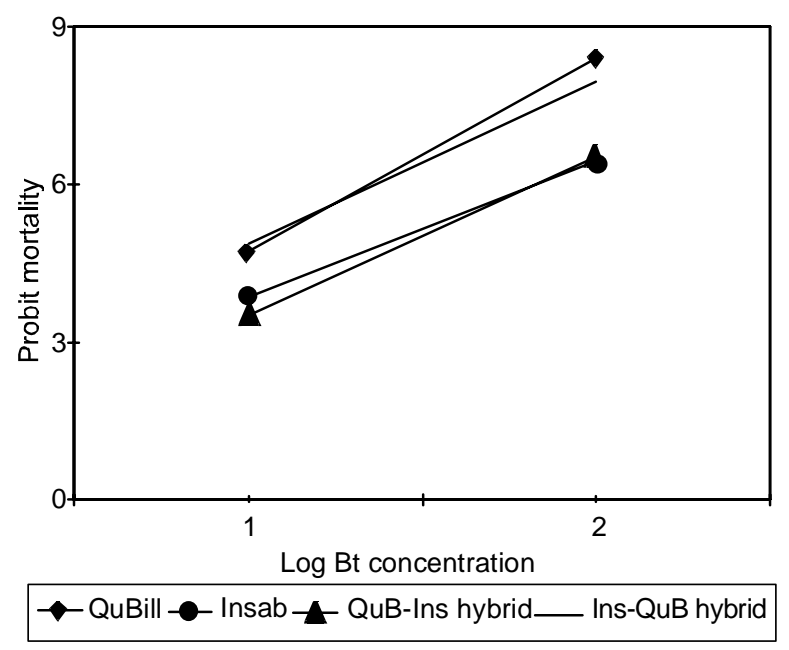

Fig. 3. Bt Concentration - Probit mortality in parents and hybrids at $72 \mathrm{~h}$ after treatment. steeper. At the $48 \mathrm{HAT}$, the calculated regression lines were $\mathrm{Y}=0.75+2.74 \mathrm{X}$ for QuBill, $\mathrm{Y}=1.57+1.66 \mathrm{X}$ for Insab, $\mathrm{Y}=0.57+2.07 \mathrm{X}$ for QuB-Ins hybrids and $\mathrm{Y}=1.31+$ 2.45X for Ins-QuB hybrids. The calculated regression lines at the 72 HAT were $Y=1.06+2.62 X$ for QuBill, $Y=1.23$ $+1.87 \mathrm{X}$ for Insab, $\mathrm{Y}=0.49+2.16 \mathrm{X}$ for QuB-Ins hybrids and $\mathrm{Y}=1.75+2.21 \mathrm{X}$ for Ins-QuB hybrids.

The comparative Bt-tolerance and susceptible responses of two new hybrids (QuB-Ins hybrid and Ins-QuB hybrid) and parent (QuBill and Insab) populations showed that the Bt mortality rates were $\mathrm{Bt}$ dose and time dependent. The larval mortality rates increased with the higher doses of $\mathrm{Bt}$, and highest mortalities were observed at $72 \mathrm{~h}$ after the treatment. Jayanthi and Padmavathamma (1997) reported that larval mortality rates of $B$. mori were decreased in lower concentrations of $B$. thuringiensis (Bt). Our results are in consistent with them, as we also observed significant decreases at larval mortality at lower doses of Bt.

The $\mathrm{LD}_{50}$ values against $\mathrm{Bt}$ doses at 24, 48 and $72 \mathrm{HAT}$, showed the 'Ins-QuB hybrid' with the lowest $\mathrm{LD}_{50}$ and closely related to its Bt tolerant male parent "QuBill”. On the other hand, the "QuB-Ins hybrid" showed the highest $\mathrm{LD}_{50}$, closely related to its $\mathrm{Bt}$ susceptible male parent "Insab" (Table 2). The above phenomena indicated the possibility of flow of Bt-tolerance property from the male parents to their progenies.

The sex chromosomes of the silkworm B. mori, are designated ZW for the heterogametic female and ZZ for the homogametic male (Yokoyama et al., 2003; Nagaraju, 1996). The W-chromosome strongly determines femininity and it has been successfully used to produce different genetic stocks with dominant alleles for egg colour, larval markings and cocoon colour (Ohbayashi et al., 2002; Nagaraju, 1996). However, references were not available regarding the association of $\mathrm{Z}$ or $\mathrm{W}$ chromosome with transfer of a disease tolerance or susceptibility.

This preliminary investigation on the relative toxicity of Bt doses on new hybrids and their parent silkworm populations clearly showed that the "QuB-Ins hybrid" population had the highest Bt-tolerance capability, followed by its male Insab parent population. In the case of Bt-susceptibility, it was also observed a similar relationship between the "Ins-QuB hybrid" and its male parent "QuBill” population. Unfortunately, the references on the association of the $\mathrm{W}$ or $\mathrm{Z}$ chromosome with the transfer of disease tolerance/ susceptible genetic character 
from the parents to offspring are scanty. However, with the current experimental results, it may be hypothesized that as both hybrids were expressing their Bt- tolerance or susceptible characteristics similar to their male parents only, there is a possibility that the "Bt-tolerance" or BtSusceptible" character was acquired from their male parents. However, further detailed study is needed to establish the chromosome associated with the transfer of this genetic character from the parents to hybrids.

\section{Acknowledgement}

The authors are thankful to Rural Industries Research and Development Corporation (RIRDC) for their support and a postgraduate scholarship to the main author.

\section{References}

Aruga, H. 1994. Principles of Sericulture, 376 pp. (translated from Japanese). A.A. Balkema, Rotterdam, The Netherlands.

Balavenkatasubbaiah, M., Ananthalakshmi, K.V.V., Selvakumar, T. , Nataraju, B., Datta, R.K. 1999. Chlorine dioxide, a new disinfectant in sericulture. Indian Journal of Sericulture, 38: 125-130.

Begum, H.A., Hassan, E., Dingle, J. 2004. Resistance of three different populations of mulberry silkworm (Bombyx mori L.) to Bacillus thuringiensis. Journal of Plant Diseases and Protection, 111: 231-237.

Duncan, D.B. 1951. A significance test for differences between ranked treatments in an analysis of variance. Virginia Journal of Science, 2: 171-189.

Finney, D.J. 1971. Statistical Method in Biological Assay, 668 pp., $2^{\text {nd }}$ edition - Griffin, London, UK. Ibiza-Palacios, M.S., Ferré, J., Higurashi, S., Miyamoto, K., Sato, R., Escriche, B. 2008. Selective inhibition of binding of Bacillus thuringiensis Cry1Ab toxin to cadherin-like and aminopeptidase proteins in brush-border membranes and dissociated epithelial cells from Bombyx mori. Biochemical Journal, 409: 215-221.

Inagaki, S., Miyasono, M., Yamamoto, M., Ohba, K. , Ishiguro, T., Takeda, R., Hayashi, Y. 1992. Induction of antibacterial activity against. Bacillus thuringiensis in the common cutworm, Spodoptera litura (Lepidoptera: Noctuidae). Applied Entomology and Zoology, 27: 565-570.
Jayanthi, P.D.K., Padmavathamma, K. 1997. Laboratory evaluation of toxicity of Bacillus thuringiensis subsp. kurstaki to larvae of mulberry silkworm, Bombyx mori L. Journal of Entomological Research, New-Delhi, 21: 45-50.

McNall, R.J., Adang, M.J. 2003. Identification of novel Bacillus thuringiensis Cry1Ac binding proteins in Manduca sexta midgut through proteomic analysis. Insect Biochemistry and Molecular Biology, 33: 999-1010.

Morin, S., Biggs,R.W., Sisterson, M.S., Shriver, L., Ellers-Kirk, C., Higginson, D., Holley, D., Gahan, L.J., Heckel, D.G., Carrière, Y., Dennehy, T.J., Brown, J.K., Tabashnik, B.E. 2003. Three cadherin alleles associated with resistance to Bacillus thuringiensis in pink bollworm. Proceedings of the National Academy of Sciences, USA, 100: 50045009.

Nagaraju, J. 1996. Sex determination and sex-limited traits in the silkworm, Bombyx mori: Their applications in sericulture. Indian Journal of Sericulture, 35: 83-89.

Ohba, M. 1996. Bacillus thuringiensis populations naturally occurring on mulberry leaves: A possible source of the populations associated with silkwormrearing insectaries. Journal of Applied Bacteriology, 80: $56-64$.

Ohbayashi, F., Suzuki, M.G., Shimada, T. 2002. Sex determination in Bombyx mori. Current Science, 83: 466-471.

Pramanik, A., Somchoudhury, A.K. 2001. Adverse effect of Bacillus thuringiensis Berliner on silkworm, Bombyx mori L. and other beneficial nontarget organisms. Journal of Entomological Research, (New Delhi), 25: 53-57.

Rahman, M.M., Roberts, H.L.S., Sarjan, M., Asgari, S., Schmidt, O. 2004. Induction and transmission of Bacillus thuringiensis tolerance in the flour moth Ephestia kuehniella. Proceedings of the National Academy of Sciences, USA., 101: 2696- 2699.

Raymond, B., Johnston, P.R., Nielsen-LeRoux, C., Lereclus, D., Crickmore, N. 2010. Bacillus thuringiensis: an impotent pathogen? Trends in Microbiology, 18: 189-194.

Van Driesche, R.G., Bellows, J.T.S. 1996. Biological Control. 539 pp. Chapman and Hall, New York, USA. 
Yokoyama, T., Abe, H., Irobe, Y., Saito, K., Tanaka, N., Kawai, S., Ohbayashi, F., Shimada, T., Oshiki, T. 2003. Detachment analysis of the translocated $\mathrm{W}$ chromosome shows that the female-specific randomly amplified polymorphic DNA (RAPD) marker, Female-218, is derived from the second chromosome fragment region of the translocated $\mathrm{W}$ chromosome of the sex-limited $\mathrm{p}(\mathrm{B})$ silkworm (Bombyx mori) strain. Hereditas, 138: 148-153. 